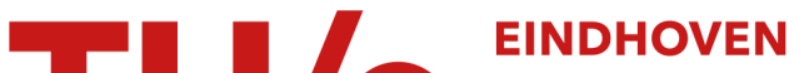

\section{Methanol from synthesis gas over bimetallic FePd catalysts}

\section{Citation for published version (APA):}

Niemantsverdriet, J. W., Grondelle, van, J., \& Kraan, van der, A. M. (1988). Methanol from synthesis gas over bimetallic FePd catalysts. Hyperfine Interactions, 41(1-4), 677-680. https://doi.org/10.1007/BF02400481

DOI:

10.1007/BF02400481

Document status and date:

Published: 01/01/1988

\section{Document Version:}

Publisher's PDF, also known as Version of Record (includes final page, issue and volume numbers)

\section{Please check the document version of this publication:}

- A submitted manuscript is the version of the article upon submission and before peer-review. There can be important differences between the submitted version and the official published version of record. People interested in the research are advised to contact the author for the final version of the publication, or visit the $\mathrm{DOI}$ to the publisher's website.

- The final author version and the galley proof are versions of the publication after peer review.

- The final published version features the final layout of the paper including the volume, issue and page numbers.

Link to publication

\section{General rights}

Copyright and moral rights for the publications made accessible in the public portal are retained by the authors and/or other copyright owners and it is a condition of accessing publications that users recognise and abide by the legal requirements associated with these rights.

- Users may download and print one copy of any publication from the public portal for the purpose of private study or research.

- You may not further distribute the material or use it for any profit-making activity or commercial gain

- You may freely distribute the URL identifying the publication in the public portal.

If the publication is distributed under the terms of Article 25fa of the Dutch Copyright Act, indicated by the "Taverne" license above, please follow below link for the End User Agreement:

www.tue.nl/taverne

Take down policy

If you believe that this document breaches copyright please contact us at:

openaccess@tue.nl

providing details and we will investigate your claim. 


\title{
METHANOL FROM SYNTHESIS GAS OVER BIMETALLIC FePd CATALYSTS
}

\author{
J.W. NIEMANTSVERDRIET, J. VAN GRONDELLE and A.M. VAN DER KRAAN* \\ Laboratory for Inorganic Chemistry and Catalysis, Eindhoven University of Technology, \\ $5600 \mathrm{MB}$ Eindhoven, The Netherlands \\ * Interuniversitair Reactor Instituut, $2629 \mathrm{JB}$ Delft, The Netherlands
}

\begin{abstract}
Bimetallic $\mathrm{FePd} / \mathrm{SiO}_{2}$ catalysts exhibit higher activities in the formation of methanol from synthesis gas than $\mathrm{Pd} / \mathrm{SiO}_{2}$. The catalysts are a complex mixture of bcc and fcc FePd alloy, $\alpha$-Fe and some unreduced iron.
\end{abstract}

\section{INTRODUCTION}

At present the production of fuels from synthesis ges is economically unattractive. The reaction to oxygenates, however, remains a viable application of $\mathrm{CO}+\mathrm{H}_{2}$ chemistry. The performance of $\mathrm{Rh}$, Pd, and Ir catalysts in the oxygenate synthesis at elevated pressures (2-7 MPa) can be improved by adding a second metal such as iron /1-4/. In this paper we show that Fe enhances the activity of $\mathrm{SiO}_{2}$-supported $\mathrm{Pd}$ for methanol formation. M४ssbauer spectroscopy and $X$-ray photoelectron spectroscopy (XPS) show that the $\mathrm{FePd} / \mathrm{SiO}_{2}$ catalysts are a complex mixture of bcc and fcc FePd alloy, $\alpha-\mathrm{Fe}$ and some unreduced iron.

\section{EXPERIMENTAL}

Catalysts were prepared by adding dropwise an aqueous solution ( $\mathrm{pH}=1$ ) of $\mathrm{PdCl}_{2}$ (Merck p.a.) and $\mathrm{Fe}\left(\mathrm{NO}_{3}\right)_{3} \cdot 9 \mathrm{H}_{2} \mathrm{O}$ (Baker) to the $\mathrm{SiO}_{2}$ support (Aerosil $300 \mathrm{~V}$, $300 \mathrm{~m} / \mathrm{g})$ until incipient wetness. Three different catalysts were prepared, 5 wt\% $\mathrm{Pd} / \mathrm{SiO}_{2}, 1: 1$ FePd/SiO 2 with 3.3 wt\% $\mathrm{Pd}$ and 1.7 wt\% $\mathrm{Fe}$ (10\% enriched in $57 \mathrm{Fe})$, and $1: 5 \mathrm{FePd} / \mathrm{SiO}_{2}$ with $4 \mathrm{wt} \% \mathrm{Pd}$ and $0.4 \mathrm{wt} \% \mathrm{Fe}(90 \% 57 \mathrm{Fe})$. Samples were dried in air at $295 \mathrm{~K}$ for $72 \mathrm{~h}$, at $320 \mathrm{~K}$ for $18 \mathrm{~h}$, and at $400 \mathrm{~K}$ for $72 \mathrm{~h}$. After reduction, $\mathrm{CO}$ hydrogenation was carried out in a copper-coated stainless steel reactor in $3 \mathrm{H}_{2}+\mathrm{CO}$ (GHSV $=4000 / \mathrm{h}, 1 \mathrm{ml}$ catalyst, density $0.47 \mathrm{~g} / \mathrm{ml}$ ) at 4.0 $\mathrm{MPa}$ (gauge) and $545 \mathrm{~K}$.

Mossbauer spectra were obtained in situ as described elsewhere /5/. Spectra were fitted with calculated subspectra consisting of Lorentzian-shaped lines by varying the MUssbauer parameters (IS, QS, $H, \varepsilon^{\prime}, \Gamma$, and area) and the background parabola coefficients in a non-linear, iterative minimization routine $/ 6 /$.

\section{RESULTS AND DISCUSSION}

Combination of iron and palladium in a bimetallic catalyst enhances the $c 0$ hydrogenation activity, while the favorably high methanol (MeOH) selectivity of $\mathrm{Pd}$ is retained (Fig. 1 and Table 1). Unfortunately, the most active catalyst, 1:1 FePd/ $\mathrm{SiO}_{2}$, deactivates severely (Fig. 1a). An interesting feature of the $1: 1$ $\mathrm{FePd} / \mathrm{SiO}_{2}$ catalyst is that it develops its $\mathrm{MeOH}$ selectivity during the first 8 hours of the reaction. A similar slow activation has been observed with ironrich $\mathrm{FeIr} / \mathrm{SiO}_{2}$ catalysts $/ 4 /$.

Fukushima et al. $/ 3 /$ report $\mathrm{MeOH}$ selectivities below $50 \%$ for $\mathrm{FePd} / \mathrm{SiO}_{2}$ catalysts with $\mathrm{Fe} / \mathrm{Pd}$ ratios higher than 0.33 . Our 1:1 $\mathrm{FePd} / \mathrm{SiO}_{2}$ catalyst, however, has a favorable MeOH activity of $82 \%$, provided we wait for steady state conditions. The reason for the apparent discrepancy is most probably that the data in ref. /3/ have been obtained after a relatively short time of 4 hours /2/. As our results show, iron-rich $\mathrm{FePd}$ and $\mathrm{FeIr} / \mathrm{SiO}_{2} / 4$ / catalyst may not yet be at steady state after such a short time. 

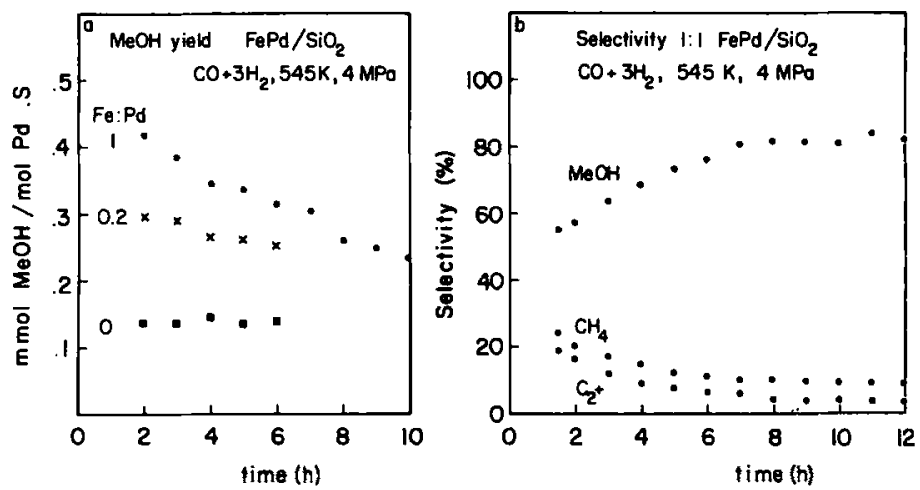

Fig. 1. Methanol (MeOH) from synthesis gas over $\mathrm{Pd} / \mathrm{S} 1 \mathrm{O}_{2}$ and $\mathrm{FePd} / \mathrm{SiO}_{2}$ catalyst. a) $\mathrm{MeOH}$ yield per mole of the precious metal Pd, and b) Selectivity of the 1:1 FePd/ $\mathrm{SiO}_{2}$ catalyst during the first 12 hours of synthesis. The selectivities of $1: 5 \mathrm{FePd} / \mathrm{SiO}_{2}$ and $\mathrm{Pd} / \mathrm{SiO}_{2}$ are at a steady state level of 95 and $92 \% \mathrm{MeOH}$, respectively.

Table 1. Steady state selectivities in $\%$ of converted $\mathrm{CO}$ of $\mathrm{FePd} / \mathrm{SiO}_{2}$ catalysts in $\mathrm{CO}+3 \mathrm{H}_{2}$ at $545 \mathrm{~K}$ and $4 \mathrm{MPa}$.

\begin{tabular}{ccrccc}
\hline $\mathrm{Fe} / \mathrm{Pd}$ & $\mathrm{CH}_{3} \mathrm{OH}$ & $\mathrm{CH}$ & $\mathrm{C}_{2}+$ & $\mathrm{DME}$ & $\mathrm{MeAc}$ \\
\hline 0 & 92.3 & 3.1 & & 3.4 & \\
0.2 & 95.0 & 2.5 & & 1.6 & \\
1 & 82.3 & 9.0 & 3.7 & & 4.1 \\
$\mathrm{Fe} \mathrm{3} \mathrm{wt \%}$ & 13.5 & 33.0 & 40 & - & - \\
\hline
\end{tabular}

$C_{2+}$ : ethane and higher hydrocrabons, DME: dimethyl ether, MeAc: methyl acetate.

The Mbssbauer spectra of Fig. 2 show that the reduction of iron is strongly catalyzed by $\mathrm{Pd}$. The $\mathrm{Fe}^{3+}$ of the fresh FePd catalysts is already reduced to $\mathrm{Fe}^{2+}$ by $\mathrm{H}_{2}$ at $295 \mathrm{~K}$ and $\mathrm{Fe}^{\circ}$ is formed at temperatures as low as $400 \mathrm{~K}$, as indicated by the large single peak at $0.5 \mathrm{~mm} / \mathrm{s}$ in the spectrum of $1: 5 \mathrm{FePd} / \mathrm{SiO}_{2}$. XPS shows that all $\mathbf{P d}$ is already reduced at $295 \mathrm{~K}$.

The catalysts reduced at the usual temperatures of $700-800 \mathrm{~K}$ contain iron in several different states. Table 2 list the results of curve fitting. The main differences between $1: 1$ and $1: 5 \mathrm{FePd} / \mathrm{SiO}_{2}$ are that the spectrum of the former contains iron predominantly in $\alpha-F e \quad(H=334 \quad k O e)$ and bcc FePd $(H=280 k 0 e)$, whereas the $\mathrm{fcc} F \mathrm{FePd}$ singlet (IS $=0.47 \mathrm{~mm} / \mathrm{s}$ ) prevails in $1: 5 \mathrm{FePd} / \mathrm{SlO}_{2}$. The parameters of FePd are in the renges reported in ref. $17 /$, the differences in composition are in line with the FePd phase diagram $/ 8 /$. 


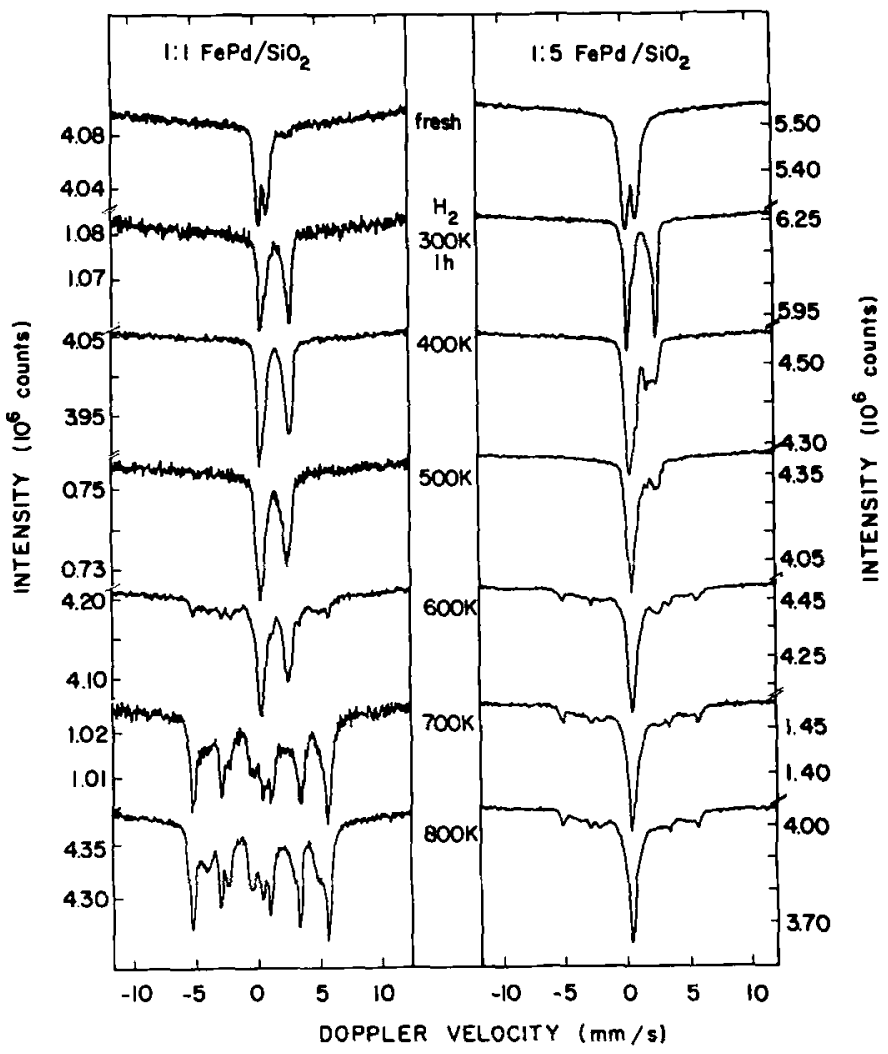

Fig. 2. In situ M४ssbauer spectra at $295 \mathrm{~K}$ of initially fresh 1:1 and 1:5 $\mathrm{FePd} / \mathrm{SiO}_{2}$ catalysts after a series of subsequent reductions in $\mathrm{H}_{2}$ for 1 hour at the indicated temperatures. The composition of the bottom spectra is given in Table 2 .

It is interesting to compare the present results on FePd catalysts and those obtained with FeIr and FePt catalysts. All three catalysts systems exhibit high methanol selectivities $(>70 \%)$ in the CO hydrogenation at $4 \mathrm{MPa} / 2-4,9 /$. Fukushima et al /2/ have suggested that ionic iron acts as promoter for the noble metals in methanol synthesis. Indeed, Mbssbauer spectra indicate that a significant fraction of the iron in FeIr and FePt/SiO 2 catalysts remains un reduced /5/. Nevertheless, evidence exists that in iron-rich $\mathrm{FeIr} / \mathrm{SiO}_{2}$ reduced iron is also involved in the sites which catalyze the reaction to methanol /9/.

The situation in $\mathrm{FePd} / \mathrm{SiO}_{2}$ is different. Here almost all iron is present in the zero-valent state. Hence, it seems likely that the beneficial effect of iron on the methanol selectivity should be attributed to its presence in an $\mathrm{FePd}$ alloy. A note of caution is appropriate, however. We cannot exclude that during reaction, zero-valent iron in the surface of the FePd, FeIr and FePt alloy particles is oxidized due to water, a by-product of the $\mathrm{CO}$ hydrogenation. Hence, the question whether ionic or metallic iron is required for the formation of methanol from $\mathrm{CO}$ and $\mathrm{H}_{2}$ can only be answered when M8ssbauer spectra of FePd, FeIr and FePt catalysts are measured in situ after the $\mathrm{CO}+\mathrm{H}_{2}$ reaction at high pressure. Such measurements will be undertaken in the near future. 
Table 2. Mossbauer parameters of iron in $\mathrm{FePd} \mathrm{SiO}_{2}$ catalysts after reduction in $\mathrm{H}_{2}$ at $800 \mathrm{~K}$.

\begin{tabular}{|c|c|c|c|c|c|c|}
\hline iron state & IS & $\begin{array}{c}\text { QS } \\
\mathrm{mm} / \mathrm{s}\end{array}$ & $\underset{\mathrm{kOe}}{\mathrm{H}}$ & $\mathrm{mm} / \mathrm{s}$ & $r$ & $\begin{array}{c}\operatorname{ares} \\
\%\end{array}$ \\
\hline $\begin{array}{l}\text { 1:1 } \mathrm{FePd} / \mathrm{SiO}_{2} \\
\mathrm{Fe} \text { in bcc } \mathrm{FePd} \\
\mathrm{Fe}^{\mathrm{O}} \text { in } \mathrm{fcc} \mathrm{FePd} \\
\mathrm{Fe}^{\mathrm{O}} \text { in } \mathrm{a}-\mathrm{Fe} \\
\mathrm{Fe}^{2+}\end{array}$ & $\begin{array}{r}.47 \\
.47 \\
.29 \\
1.24\end{array}$ & 1.54 & $\begin{array}{l}280 \\
334\end{array}$ & $\begin{array}{c}-0.03 \\
0.0\end{array}$ & $\begin{array}{l}.96^{*} \\
.75 \\
.47 \\
.72\end{array}$ & $\begin{array}{r}43 \\
8 \\
45 \\
4\end{array}$ \\
\hline $\begin{array}{l}1: 5 \mathrm{FePd} / \mathrm{SiO}_{2} \\
\mathrm{Fe} \text { in } \mathrm{bcc} \mathrm{FePd} \\
\mathrm{Fe}^{\circ} \text { in } \mathrm{fcc} \mathrm{FePd} \\
\mathrm{Fe}^{\circ} \text { in } \mathrm{a}-\mathrm{Fe} \\
\mathrm{Fe}^{2+} \\
\mathrm{Fe}^{3+}\end{array}$ & $\begin{array}{r}.51 \\
.42 \\
.26 \\
1.40 \\
.64\end{array}$ & $\begin{array}{l}1.47 \\
1.10\end{array}$ & $\begin{array}{l}263 \\
333\end{array}$ & $\begin{array}{c}-0.05 \\
0.0\end{array}$ & $\begin{array}{l}.94^{*} \\
.52 \\
.37 \\
.90 \\
.60\end{array}$ & $\begin{array}{l}24 \\
40 \\
14 \\
12 \\
10\end{array}$ \\
\hline
\end{tabular}

* Linewidth outer lines; Accuracies: IS: $0.04 \mathrm{~mm} / \mathrm{s} ; \mathrm{QS}: 0.07 \mathrm{~mm} / \mathrm{s} ; \mathrm{H}: 3 \mathrm{kOe}$; $\varepsilon^{\prime}: 0.04 \mathrm{~mm} / \mathrm{s} ; \Gamma: 0.10 \mathrm{~mm} / \mathrm{s}$; area: $5 \%$; IS relative to $\mathrm{SNP}$.

\section{REFERENCES}

/1/ M.M. Bhasin. W.J. Bartley, P.C. Ellgen and T.P. Wilson, J. Catal. 54, (1978) 120.

/2/ T. Fukushima, Y. Ishii, Y. Onda and M. Ichikawa, J. Chem. Soc., Chem. Commun. (1985) 1752.

/3/ T. Fukushima, K. Araki and M. Ichikawa, J. Chem. Soc., Chem. Commun. (1986) 148.

14/ D.C. Koningsberger, C.P.J.H. Borgmans, A.M.J. van Elderen, B.J. Kip, and J.W. Niemantsverdriet, J. Chem. Soc., Chem. Commun., in press.

/5/ J.W. Niemantsverdriet, J.A.C. van Kaam, C.F.J. Flipse, and A.M. van der Kraan, J. Catal. 96 (1985) 58.

/6/ J.W. Niemantsverdriet, Thesis, Delft, 1983.

/7/ N.V. Nair and D.C. Khan, J. Phys. F: Met. Phys. 13 (1983)1965.

/8/ 0. Kubaschevski. "Iron Binary Phase Diagrams", Springer-Verlag. Berlin 1982.

19/ J.W. Niemantsverdriet, F.W.H. Kampers, S.P.A. Louwers, J. van Grondelle. A.M. van der Kraan, and D.C. Koningsberger, in preparation. 